axis of the instrument the sound was about as effective as that of the $8 \cdot 0 z$. rocket. But in a direction at right angles to the axis, and still more in the rear of this direction, the syren fell very sensibly behind even the 2 -oz. rocket.

These are the principal comparative trirls made between the gun-cotton rocket and other fog-signals; but they are not the only ones. On August 2, 1877, for example, experiments were made at Lundy Island with the following results. At two miles distant from the firing point, with land intervening, the 18 pounder, firing a $3 \mathrm{Ib}$. charge, was quite mheard. Both the $4.0 \%$ rocket and the $8.0 \%$ rocket, however, reached an elevation which commancled the acoustic shadow, and yielded loud reports. When both were in view, the rockets were still superior to the gun. On August 6, at St. Ann's, the 4-0\%. and 8-0z. rockets proved superior to the syren. On the Shambles Light-vessel, when a pressure of $I_{3}$ lbs. was employed to sound the syren, the rockets proved greatly superior to that instrument. Proceeding along the sea-margin at Flamboro' Head, Mr. Edwards states that at $\approx$ distance of $I^{2}$ mile, with the 18 -pounder gun hidden behind the cliffs, its report was quite unheard, while the 4 -oz. rocket, rising to an elevation which brought it clearly into view, yielded a powerful sound in the face of an opposing wind.

On the evening of February 9,1877 , a remarkable series of experiments was Inade by Mr. Prentice, at Stowmarket, with the gun-cotton rocket. From the report with which he has kindly furnished me I extract the following particulars. The first column in the annexed statement contains the name of the place of observation, the second its distance from the fring-point, and the third the result observed :-

Stcket Hill, Inswich $\quad \ldots$ to miles Rockets clearly scen and sounds distinctly heard 53 seconds after the tinctly

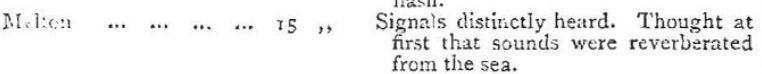
Fratuingham ... $\quad . . \quad \ldots \quad$.. 8 , $\quad$ Signuis yery distinctly heard, both in the open eir and in a closed room the open eir and in a clos

Reports loud ; startled pheasants in a

Stratford. St. Andrews., ig , cover close ; s.

Tuldentum. St. Martin so , Reports very loud; rolled away like thunder.

Christ Church Park ... II " Reprt arrived a little more than a

Christ Church Park ... II " Report arrived a little more than a Nettlestead Hall ... ... 6, Distinct in every part of observer'

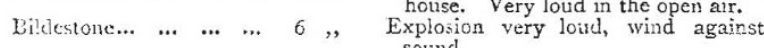
sound.

$\begin{array}{llllllll}\text { Nacton } & \ldots & \ldots & \ldots & \ldots & \text { I4 } & , & \begin{array}{c}\text { Reports quite distinct }- \text { mistaken by } \\ \text { inhabitants for claps of thunder. }\end{array} \\ \text { Aldiboro } & \ldots & \ldots & \ldots & \ldots & 25 & , & \text { Rockets seen through a very hazy }\end{array}$

$\begin{array}{llllllll}\text { Nacton } & \ldots & \ldots & \ldots & \ldots & \text { I4 }_{4}, & \begin{array}{c}\text { Reports quite distinct-mistaken by } \\ \text { inhabitants for claps of thunder. } \\ \text { Rockets seen through a very hazy }\end{array} \\ \text { Alaboro } & \ldots & \ldots & \ldots & \ldots & 25 & ,, & \end{array}$ atmosphere; a rumbling detonation heard.

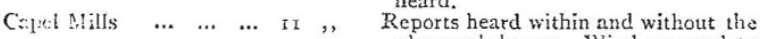
observer's house. Wind opposed to sound.

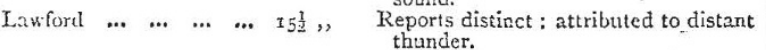

It is needless to dwell for a moment on the advantage of possessing a signal commanding ranges such as these.

The explosion of substances in the air, after having been carried to a considerable elevation by rockets, is a familiar performance. In 1873 , moreover, the Board of Trade proposed a light-andsound rocket as a signal of distress, which proposal was subseciuently realised, but in a form too elaborate and expensive for practical use. The idea of the gun-cotton rocket with a view to signalling in fogs is, I believe, wholly due to the Deputy Master of the Trinity House. ${ }^{1}$ Thanks to the skilful aid given by the authorities of Woolwich, by Mr. Prentice, and Mr. Biock, that iden is now an accomplished fact, a signal of great power, handiness, and economy, being thus placed at the service of our matiners. Not only may the rocket be applied in association with lighthouses and lightships, but in the Navy also it may be lurned to important account. Soon after the loss of the Vanguard I veñtured to urge upon an eminent naval officer the desirability of having an organised code of fog-signals for the fleet. He shook his head doubtingly, and referred to the difficult of finding room for signal-guns. The gun-cotton rocket completely surmounts this difficulty. It is manipulated with ease and rapidity, while its discharges may be so grouped and combined as to give a most important extension to the voice of the admiral in command.

I have referred more than once to the train of echoes which accompanied the explosion of gun cotton. in free air, speaking of them as similar in all respects to those which were speaking of

II have proposed that it should be called the "Collinson Rocket," the first time in my report on fog-signals, acldressed to the Corporation of Trinity House in $1874 .{ }^{I}$ To these echoes I at tached a fundamental significance. There was no visible reflecting surface from which they could come. On some days, with hardly a cloud in the air, and hardly a ripple on the sea, they reached us with magical intensity. As far as the sense of hearing could judge, they came from the body of air in front of the great trumpet which produced them. The trumpet-blasts were five seconds in duration, but long before the blast had ceased the echoes struck in, adding their strength to the primitive note of the trumpet. After the blast had ended the echoes continued, retreating further and further from the point of observation, and finally dying away at great distances. The echoes were perfectly continuous as long as the sea was clear of slips, "tapering "by imperceptible gradations to absolute silence. But when a ship happened to throw itself athwart the course of the sound, the echo from the broadside of the vessel was returned as a shock which rudely interrupted the continuity of the dying atmospheric music.

The day on which our latest observations were made was particularly fine. Before reaching Dungeness the smoothmess of the sea and the serenity of the air caused me to test the echoing power of the atmosphere. A single ship lay about half a mile distant between us and the land. The result of the proposed experiment was clearly foreseen. It was this. The rocket being sent up, it exploded at a great height; the echoes retreated in their usual fashion, becoming less and less intense as the distance of the surfaces of reflection from the observers increased. About five seconds after the explosion, a single loud shock was sent back to us from the side of the vessel lying between us and the land. Obliterated for a moment by this more intense echo, the aïrial reverberation continued its retreat, dying away into silence in two or three seconds afterwards.

I have referred to the firing of an 8-oz, rosket from the deck of the Galater, on March 8, 1877, stating the cluration of its echoes to be seven seconds. Mr. I'rentice, who was present o.t the time, assured me that, in his experiments with rockets, similar echoes had been frequently heard of more tiran twicc this duration. The ranges of his sounds alone woull renjer this result in the highest degree probable.

There is not a feature connected with the aërial echoes which cannot be brought out by experiments in the laboratory. I have recently made the following experiment:-A rectangle 22 inches by $\mathrm{I} 2$, is crossed by twenty-three brass tubes, each having a slit along it from which gas can issue. In this way, twenty-three low, flat flames are obtainecl. A sounding reed, fixed in a short tube, is placed at one end of the rectangle, and a "sensitive flame" at some distance beyond the other end. When the reed sounds, the flame in front of it is violently agitated, and roars boisterously. Turning on the gas, and lighting it as it issues from the slits, the air above the flames becomes so heterogeneous that the sensitive flame is instantly stilled by the aërial reflection, rising from a height of 6 inches to a height of 18 inches. Here we have the acoustic opacity of the air in front of the South Foreland strikingly imitated. Turning off the gas, and removing the sen. sitive flame to some distance behind the reed, it burns there iranquilly, though the reed may be sounding. Again lighting the gas as it issues from the brass tubes, the sound reflected from the heterogeneous air throws the sensitive flame into violent agitation. Here we have imitated the aërial echoes heard $\bar{t}$ when standing behind the syren-trumpets at South Foreland. The expsriment is extremely simple and in the highest degree impresssive.

\section{THE IRON AND STEEL INSTITUTE}

THE ninth annual meeting of the members of the Iron and Steel Institute was commenced on Thursday in the rooms of the Institution of Civil Engineers in Westminster. The chair was occupied by Dr. C. W. Siemens, F.R.S., the President of the Institute, and the proceedings were commenced by the read. ing of the Annual Report of the Council, which stated that the total number of members now exceeds 900 , while a steady accession of new members cöntinues, there being 47 proposed for election at the present meeting. The Council referred to the increase of foreign members, which shows the interest taken in the institute by Continental and American metallurgists. An invitation received from $M$. Tresca on behalf of the Société des Ingénieurs Civils, to visit Paris in the ensuing summer and the concurrent holding of the International Exhibition in that city, I See also Phitosophical Transactions for 1874, p. 183 . 
have irriuced the Council to recommend that the next autumn meeting should be held in Paris. A sum of 2,318l. has been raised by the Institute for the widow and family of Mr. Jones, the late general secretary,

The President stated that the Bessemer medal had been ax arded to Prof. Tunner, of Leoben, Austria, in consequence of ihe great distinction that gentleman had earned for himself in $l$ is rescarches in that branch of science which the Institute so specially represented.

One of the most important papers read was by Mr. I. Lowthian Bell, M.P., F.R.S., on the separation of phosphorus from pig iron. In this paper Mr. Bell detailed his further expericnces in his endeavours to eliminate the phosphortus from the iron, its presence having a weakening effect on the metal. Fully five-sixtins of the pig iron manufactured in Great Britain is made from orcs which, when smelted, give a product containing from three-tenths of a unit to nearly 2 per cent. of phosphorus. When, however, this element exists in pig iron to the extent of much more than one-tenth of a unit per cent. it is unfit for the Bes. semer converter-at all events when ordinary spiegel iron, containing IO or I2 per cent. of manganese, is used for its final purification. Bessemer steel rail-makers are, therefore, obliged to reject iron which formerly sufficed for the manufacture of iron mils, an iron comparatively free from phosphorus being necessary. That, therefore, affected the prosperity of the mines which formerly supplied the rail makers with ore, as well as the blast farnaces which produced the pig iron from that ore. Mr. Bell cxplaired that at the high temperature of the Bessemer converter, while the carbon was removed by the air during its passage through the metal, the phosphorus was not affected. This he stated was also the case to a certain extent in the ordinary refinery furnaces; with a more moderate temperature, however, the conditions which bound carbon and phosphorus with iron were materially changed. The iron was more or less oxidised, and the oxide of iron so formed acted on the carbon and phosphorus. When the phosphorus is removed its loss is accompanied by a separation of the carbon contained in the pig iron. Loss of carbon, however, cleprives the metal of its susceptibility of fusion at the temperatures at which the cperation of refining and pudding are carried on, and when once the metal is solid the further elimination of phosphorus is very difficult, if not impossible. Mr. Bell expressed the opinion that a lower tempera ture probably weakened the affinity of phosphorus for iron, as they existed in the crude metal, or strengthened the affinity between oxide of iron and phosphoric acid. A third condition involved in the mere condition of heat might be a diminution of the power poss ssed by oxide of iron in attacking the carbon, that elcment which enabled the crude metal to maintain fluidity when moderately heated. The author said that whichever one or more than one of the three conditions was required, the fact remained that melted crude iron might be maintained in contact with melted oxide of iron, and still retain carbon enough to prevent it solidifying, while the phosphorus rapidly disappeared. Instances were given of 95 per cent. of phosphorus being removed, while only ro per cent of the carbon had been dissipated. The process consists in the more rapid agitation of the two substances while in a liquid condition. The iron so heated may be puddled for the production of malleable iron, or used for the manufacture of steel. Specimens of steel of the highest quality which had been so produced at the Royal Arsenal, Woolwich, were exhibited.

Dr. Percy, F.R.S., gave some particulars as to the manufacture of Japanese copper. Bars of this metal present a beautiful rose. coloured tint on their surface, which is due to an extremely thin and pertinaciously adherent film of red oxide of copper or cuprous oxide. This tint is not in the least degree affected by fre exposure to the atmosphere. Ir. Percy placed before the meeting bars which he had possessed for thirty years, and which had undergone no change, although freely exposed to the atmosphere. The secret of this result lies in casting the copper under water, the metal being very highly heated and the water being also made hot. Dr. Percy stated that he had succeeded in casting copper in this way, and had produced similar results to those shown in the Japanese metal.

Other papers read were:- "On some Recent Improvements in the Manufacture of Iron Sponge by the Blair Process," by Mr. J. Ireland ; "Statistics on the Production and Depreciation of Rails," by Mr. Charles Wood; "On Steel-casting Apparatus," by Mr. Michael Scott; "On Railway Joints," by Mr. C. H. Halcomb ; and "On the Manufacture of Bessemer Steel and Steel Rails," by Mr. C. B. Holland.
UNIVERSITY AND EDUCATIONAL INTELLIGENCE

CAMBRIDGE, - The Council of the Senate recommend that the application of Prof, C. C. Babington for skilled assistance at the Botanical Museum be granted, and that an assistant curator of the Herbarium be appointed at a salary of rool. per annum, the appointment to be made by the Professor with the consent of the Vice-Chancellor, and to be for a period of four years. It is in contemplation to appoint a non-collegiate student.

Baltimore.-The Anniversary of the Johns Hopkins University was celebrated on February 22 , when addresses were given by some of the professors and others. So far the progress of the University has been thoroughly satisfactory. One of its principal aims is to encourage original research, both among professors and students, and fellowships are granted to those who show aptitude for such work. Prof. Remsen, in his address, showed that a lofty idea of what original research really is, is entertained at the University ; it is not merely the establishing of an isolated fact, the devising of a new piece of apparatus, the simple analysis of a new mineral, the discovery of an extra tooth in some abnormal animal; it is, rather, a systematic attempt to solve a definite problem, involving the use of a variety of methods peculiar to the special branch in which the attempt is made. In the three laboratories, biological, physical, and chemical, a variety of important work is being carried on, and altogether, both in the kind and amount of work which is being done under the anspices of the university, the trustees and professors show that they have a thorough appreciation of the spirit of the founder's legacy.

\section{SOCIETIES AND ACADEMIES \\ LONDON}

Mathematical Society, March 14,--Lord Rayleigh, F.R.S., president, in the chair.-Mr. Artemas Martin, Erie, Pa., was proposed for election. - The Secretary communicated a paper by Prof. J. Clerk Maxwell, on the electrical capacity of a long narrow cylinder and of a disc of sensible thickness. Prof. Cayley, Mr. J. W. L. Glaisher, Mr. Roberts, and the President made short communications.

Royal Astronomical Society, March 8.-Lord Lindsay, president, in the chair.-Mr. Neison read a paper on Hansen's terms of long period in the Iunar theory. Mr. Proctor drew some diagrams referring to the position of the axis of Mars, and spoke upon Mr. Stone's paper of Inst January. Mr. Neison made some illustrative remarks thereon. - A paper by $\mathrm{Mr}$. Plummer was read on the supposed influence of a mass of brickwork upon the errors of a transit instrument in its neighbour. hood. Several Fellows commented upon this papey and described the lively behaviour of their transit-piers; Mr. Dunkin said there was nothing new about it. - A paper by Mr. Stone was read on telescopic observations of the Transit of Venus. Mr. Gill spoke on the difficulties concerning contacts, and some discussion followed.-A paper was announced by Prof. Sedley Taylor on Galileo's trial before the Inquisition in the light of recent researches; likewise an atlas of the ecliptic, by Heiss, of stars down to the fifth magnitude on Mercator's projection, made in order to get people to lay down the zodiacal light. - There were several other papers.

Entomological Society, March 6.--H. W. Bates, F.L.S., F.Z.S., president, in the chair.-Mr. John Woodgate was elected a Member of the Society.-Mr. F. Moore, at the request of Sir W. H. Gregory, late governor of Ceylon, exhibited a large series of drawings, executed by native artists, of the transformations of the lepidoptera of the island. These drawings were made under the direction of Dr. Thwaites, and represented, for the first time, the life-history of many species.-Mr. McLachlan exhibited some entomological parts of the great Russian work "Fedtschenkos' Traveis in Turkestan." -Mr. H. Goss exhibited a smal collection of fossil insects obtained by Mr. Gardner from the Bournemouth leaf beds (middle eocene). The collection comprised numerous elytra of coleoptera, and wings of neuroptera, \&c-Mr. J. Mansel Weale read some notes on South African insects. These referred to variation in Pieris severina and Pieris mesenina; to the secretion of formic acid in Termes triniverius, and the probable localisation of the same in a cephalic process, and also to the larvæ of some Ylesperidæ in relation to the subject of protective resemblance. $-\mathrm{Mr}$. Ed. Saunders read a paper entitled "Remarks on the Hairs of some of our Briti:h Hymen- 